\title{
PENERAPAN AJARAN PENYERTAAN DALAM TINDAK PIDANA KECELAKAAN LALU LINTAS YANG DILAKUKAN OLEH ANAK (Studi Perkara di Wilayah Hukum Pengadilan Negeri Purworejo)
}

\author{
Endi Nurindra Putra \\ Magister Ilmu Hukum Fakultas Hukum Universitas Jenderal Soedirman
}

\begin{abstract}
The number of cases that forced children to be responsible for a criminal offence committed traffic accident has become the concern of various parties. This research focuses on the application of the inclusion in the crime of traffic accidents committed by children in State Court jurisdiction Purworejo. The methods used in this research is with the juridical normative approach, through the study of the legislation, principles of law, and the doctrine. Parents who commit gross negligence or forgetfulness of its responsibility to nurture, maintain, educate and protect children are convicted and could be sued for damages by using the teaching of criminal law with the inclusion in its form as Advocacy (uitlokking) and Pembantuan (medeplichtige). In eksepsional using the principle of liability in a type of renewal of criminal law. Progressive thinking in this research are expected to embody the law enforcement-oriented children's best interests.
\end{abstract}

Keywords: Teaching, Criminal Liability, the inclusion of forgetfulness.

\begin{abstract}
Abstrak
Banyaknya kasus yang memaksa anak harus bertanggung jawab atas tindak pidana kecelakaan lalu lintas yang dilakukannya telah menjadi keprihatinan berbagai pihak. Penelitian ini menitikberatkan pada penerapan ajaran penyertaan dalam tindak pidana kecelakaan lalu lintas yang dilakukan oleh anak di wilayah hukum Pengadilan Negeri Purworejo. Metode yang digunakan dalam penelitian ini adalah dengan pendekatan yuridis normatif, melalui studi terhadap peraturan perundang-undangan, asas hukum, dan doktrin. Orang tua yang berbuat kelalaian atau kealpaan dari tanggung jawabnya untuk mengasuh, menjaga, mendidik dan melindungi anak dapat dipidana dan dituntut ganti kerugian dengan menggunakan ajaran penyertaan dalam hukum pidana dengan bentuknya sebagai Penganjuran (uitlokking) dan Pembantuan (medeplichtige). Secara eksepsional menggunakan prinsip vicarious liability dalam pembaharuan hukum pidana. Pemikiran progresif dalam penelitian ini diharapkan mampu mewujudkan penegakan hukum yang berorientasi pada kepentingan terbaik untuk anak.
\end{abstract}

Kata kunci: Ajaran Penyertaan, Pertanggungjawaban Pidana, Kealpaan.

\section{Pendahuluan}

Anak sebagai bagian dari generasi muda merupakan mata rantai awal yang penting dan menentukan dalam upaya menyiapkan dan mewujudkan masa depan bangsa dan negara. Apabila anak kurang mendapat perhatian dari lingkungan terdekatnya maka mudah baginya untuk melakukan perbuatan yang menyimpang dari norma hukum yang berlaku di masyarakat. Semua perilaku anak yang akhirnya menjurus pada perbuatan kriminal membutuhkan penanganan hu- kum secara serius, khususnya perlindungan hakhak anak dalam proses peradilan pidana.

Dewasa ini kenakalan anak semakin meningkat baik secara kualitas maupun kuantitas, dan yang memprihatinkan lagi kenakalan yang dilakukan anak tersebut bukan lagi kenakalan biasa karena cenderung mengarah pada perbuatan kriminal, bahkan dengan korban anak sekalipun. Kedudukan anak sebagai pelaku tindak pidana dan anak sebagai korban tindak pidana, mendorong keprihatinan banyak pihak untuk memberikan perhatian khusus terhadap perkara tersebut, terma- 
suk lembaga peradilan. Lembaga peradilan dalam hal ini, mempunyai peranan penting dalam menjamin perlindungan hak-hak anak, baik sebagai pelaku maupun korban. Hakim sebagai pejabat yang mempunyai wewenang dalam memeriksa dan memberikan putusan atas tindak pidana yang dilakukan anak, harus dapat memberikan putusan yang tepat dan dapat memenuhi rasa keadilan bagi masyarakat pada umumnya serta hak-hak anak yang menjadi pelaku dan hak-hak anak yang menjadi korban pada khususnya.

Hakikatnya anak tidak dapat melindungi diri sendiri dari berbagai macam tindakan yang menimbulkan kerugian mental, fisik, sosial dalam berbagai bidang kehidupan dan penghidupan. Anak harus dibantu oleh orang lain dalam melindungi dirinya, mengingat situasi dan kondisinya, khususnya dalam pelaksanaan peradilan pidana anak yang asing bagi dirinya. Anak perlu mendapat perlindungan dari kesalahan penerapan peraturan perundang-undangan yang diperlakukan terhadap dirinya, yang menimbulkan kerugian mental, fisik, dan sosial. Perlindungan anak dalam hal ini disebut perlindungan hukum/yuridis (legal protection). ${ }^{1}$

Fenomena kenakalan anak yang menjurus pada tindak pidana kecelakaan lalu lintas mendadak menarik untuk dicermati, tidak hanya dipicu oleh kejadian kecelakaan lalu lintas yang menimpa Abdul Qadir Jailani (AQJ) anak musisi Ahmad Dani yang disebut-sebut sebagai "sopir maut" yang masih berusia 13 (tiga belas) tahun namun diperbolehkan mengendarai mobil yang mengakibatkan kecelakaan lalu lintas pada tanggal 8 September 2013 di Tol Jagorawi dengan korban 7 (tujuh) orang meninggal dunia dan lainnya lukaluka, tetapi disebabkan kasus serupa banyak terjadi di daerah-daerah termasuk di Kabupaten Purworejo. Kejadian yang menimpa Abdul Qadir Jailani menjadi fenomenal karena akibat perbuatan si pelaku tindak pidana kecelakaan lalu lintas mengakibatkan banyak korban meninggal dunia.

Maidin Gultom, 2010. Perlindungan Hukum Terhadap Anak Dalam Sistem Peradilan Pidana Anak Di Indonesia, PT. Refika Aditama, Bandung, hal. 2.
Semua pihak baik masyarakat, pemerintah, ahli hukum, dan pengamat politik ikut memberikan komentar atas peristiwa hukum yang menarik perhatian banyak kalangan tersebut.

Demikian halnya dengan perkara tindak pidana kecelakaan lalu lintas dengan pelaku anak yang terjadi di wilayah hukum Pengadilan Negeri Purworejo. Dari jumlah perkara khusus tindak pidana kecelakaan lalu lintas yang masuk ke Pengadilan Negeri Purworejo tahun 2012 sebanyak 15 (lima belas) perkara seluruhnya didakwa melakukan tindak pidana yang karena kelalaiannya mengakibatkan kecelakaan lalu lintas, 2 (dua) diantaranya merupakan perkara anak dan dipidana penjara. $^{2}$ Banyak pihak juga memberikan perhatian terhadap pelaku, di samping oleh karena masih berusia anak, hal itu terjadi dengan pelanggaran tidak dipenuhinya Surat Izin Mengemudi (SIM) sebagai syarat mengemudikan kendaraan bermotor di jalan. Akibatnya anak harus menjalani proses peradilan pidana dan dijatuhi pidana.

Di Indonesia telah dibuat peraturan-peraturan yang pada dasarnya sangat menjunjung tinggi dan memperhatikan hak-hak dari anak yaitu diratifikasinya Konvensi Hak Anak (KHA) dengan Keputusan Presiden Nomor 36 Tahun 1990. Peraturan perundangan lain yang telah dibuat oleh pemerintah Indonesia antara lain, Undang-Undang Nomor 4 Tahun 1979 tentang Kesejahteraan Anak, Undang-Undang Nomor 3 Tahun 1997 tentang Pengadilan Anak, Undang-Undang Nomor 23 Tahun 2002 tentang Perlindungan Anak dan terakhir dengan Undang-Undang Nomor 11 Tahun 2012 tentang Sistem Peradilan Pidana Anak.

Secara substansinya undang-undang tersebut mengatur hak-hak anak yang berupa, hak hidup, hak atas nama, hak pendidikan, hak kesehatan dasar, hak untuk beribadah menurut agamanya, hak berekspresi, berpikir, bermain, berkreasi, beristirahat, bergaul dan hak jaminan sosial. Dibuatnya aturan-aturan tersebut terlihat bahwa negara sangat memperhatikan dan melindungi hak-

2 Laporan Tahunan Pengadilan Negeri Purworejo, Tahun 2012. 
hak anak yang wajib dijunjung tinggi oleh setiap orang. Pengadilan anak dibentuk sebagai upaya pembinaan dan perlindungan dalam rangka menjamin pertumbuhan dan perkembangan fisik, mental dan sosial anak secara utuh, serasi, selaras dan seimbang. ${ }^{3}$ Namun dalam penegakan hukumnya masih mengalami hambatan maupun kendala.

Berdasarkan uraian-uraian tersebut di atas, maka penelitian mengenai perkara anak yang terlibat dalam tindak pidana kecelakaan lalu lintas dan upaya mengikutsertakan orang tua dan lingkungan masyarakat terkait untuk dimintai tanggungjawab pidana atas kelalaian yang dilakukannya penting untuk dilaksanakan. Penelitian ini dilakukan dengan memperhatikan prinsip-prinsip ajaran penyertaan dalam tindak pidana.

\section{Perumusan Masalah}

Berdasarkan latar belakang tersebut di atas dapat dirumuskan permasalahan sebagai berikut: Pertama, apakah dalam tindak pidana kecelakaan lalu lintas yang dilakukan oleh anak dapat diterapkan ajaran penyertaan; Kedua, bagaimanakah bentuk-bentuk ajaran penyertaan yang dapat diterapkan dalam tindak pidana kecelakaan lalu lintas yang dilakukan oleh anak di wilayah hukum Pengadilan Negeri Purworejo.

\section{Metode Penelitian}

Penelitian ini menggunakan metode kualitatif dengan pendekatan yuridis-normatif. Digunakannya metode kualitatif, mengingat dari permasalahan yang ada hendak dicari makna yang mendalam dan rinci terhadap fenomena yang diteliti.

Spesifikasi penelitian ini adalah bersifat deskriptif-analitis sesuai dengan masalah dan tujuan penelitian ini. Penelitian dilakukan di wilayah hukum Pengadilan Negeri Purworejo sebagai sistem peradilan pidana di Kabupaten Purworejo, yaitu di Kepolisian Resort Purworejo, Kejaksaan

Bambang Waluyo, 2008. Pidana dan Pemidanaan, Sinar Grafika, Jakarta, hal. 102.
Negeri Purworejo dan Pengadilan Negeri Purworejo.

Penelitian hukum ini diperlukan data primer sebagai data pendukung yang berkaitan dengan perspektif dan pandangan penegak hukum terhadap ajaran penyertaan dalam tindak pidana kecelakaan lalu lintas yang dilakukan oleh anak dan peranan penegak hukum dalam menyelesaikan perkara tersebut. Data primer tersebut adalah data yang diperoleh langsung dari informan, yaitu para penegak hukum, polisi, jaksa dan hakim yang berwenang melakukan pemeriksaan terhadap perkara anak. Analisis data dalam penelitian ini menggunakan analisis kualitatif dengan cara berpikir deduktif.

\section{Pembahasan \\ Ajaran Penyertaan dalam Tindak Pidana Kece- lakaan Lalu Lintas yang Dilakukan oleh Anak}

Anak adalah amanah sekaligus karunia Tuhan Yang Mahaesa, yang senantiasa harus dijaga karena dalam dirinya melekat harkat, martabat, dan hak-hak sebagai manusia yang harus dijunjung tinggi. Perlindungan terhadap anak-anak di Indonesia bertujuan untuk menjamin terpenuhinya hak-hak anak agar dapat hidup, tumbuh, berkembang, dan berpartisipasi secara optimal sesuai dengan harkat dan martabat kemanusiaan, serta mendapat perlindungan dari kekerasan dan diskriminasi, demi terwujudnya anak Indonesia yang berkualitas, berakhlak mulia, dan sejahtera. Oleh karenanya, setiap anak selama dalam pengasuhan orang tua, wali, atau pihak lain mana pun yang bertanggung jawab atas pengasuhan, berhak mendapat perlindungan dari perlakuan diskriminasi; eksploitasi, baik ekonomi maupun seksual; penelantaran; kekejaman, kekerasan, dan penganiayaan; ketidakadilan; dan perlakuan salah lainnya. ${ }^{4}$ Orang tua dalam hal ini diartikan sebagai ayah dan/atau ibu kandung, atau ayah dan/atau ibu tiri, atau ayah dan/atau ibu angkat.

Pasal 13 Undang-Undang Nomor 23 Tahun 2002 tentang Perlindungan Anak. 
Mengenai adanya tindak pidana yang dilakukan oleh anak, perlu lebih dulu dipahami istilahistilah yang digunakan dalam hukum pidana. Hampir seluruh peraturan perundang-undangan menggunakan istilah tindak pidana. ${ }^{5}$ Meski banyak ahli hukum menggunakan istilah lain, seperti peristiwa pidana oleh R. Tresna, H.J. van Schravendijk dan Zainal Abidin; delik oleh Utrecht; pelanggaran pidana oleh M.H. Tirtaamidjaja; perbuatan yang boleh dihukum oleh Karni; perbuatan yang dapat dihukum oleh pembentuk UndangUndang Darurat No. 12/Drt/1951; dan perbuatan pidana oleh Moeljatno dan Roeslan Saleh, namun istilah tindak pidana sudah dapat diterima oleh masyarakat, jadi mempunyai "sociologische gelding". ${ }^{6}$ Sejalan dengan ini Satochid Kartanegara menganjurkan pemakaian istilah tindak pidana, karena istilah tindak (tindakan), mencakup pengertian melakukan atau berbuat (actieve handeling) dan/atau pengertian tidak melakukan, tidak berbuat, tidak melakukan suatu perbuatan (passieve handeling), sedangkan terjemahan pidana untuk strafbaar adalah sudah tepat. ${ }^{7}$

Tidak ditemukan definisi tentang tindak pidana dalam produk hukum undang-undang, maka dalam menjabarkan mengenai tindak pidana didasarkan pada pendapat para sarjana hukum yang selanjutnya terbagi dalam 2 (dua) pandangan yaitu pandangan Monistis dan pandangan Dualistis.

Tindak pidana anak dalam ketentuan hukum disebut dengan anak yang melakukan tindak pidana atau anak nakal. Untuk mengetahui jika pelaku merupakan anak-anak, maka perlu dilihat definisi anak, yang secara nasional didasarkan pada batasan usia anak menurut hukum dan ketentuan perundang-undangan. Diantaranya menjelaskan anak adalah seorang yang belum men-

5 Adami Chazawi, 2010, Stelsel Pidana, Tindak Pidana, Teori-Teori Pemidanaan \& Batas Berlakunya Hukum Pidana, Pelajaran Hukum Pidana Bagian I, PT. Raja Grafindo Persada, Cetakan ke-5, Jakarta, hal. 67.

6 Sudarto, 1990. Hukum Pidana I, Yayasan Sudarto Fakultas Hukum Undip, Semarang, hal. 39.

7 S.R. Sianturi, Asas-Asas Hukum Pidana Di Indonesia Dan Penerapannya, Penerbit Alumni Ahaem-Petehaem, Jakarta.hal. 203-204. capai usia 21 tahun atau belum menikah. ${ }^{8}$ Ada yang mengatakan anak adalah seseorang yang belum berusia 18 tahun $^{9}$, Undang-Undang Nomor 23 Tahun 2002 tentang Perlindungan Anak, anak adalah seseorang yang belum berusia 18 tahun dan bahkan masih di dalam kandungan ${ }^{10}$, sedangkan Undang-Undang Nomor 3 Tahun 1997 tentang Pengadilan Anak, anak adalah orang yang dalam perkara anak nakal telah mencapai usia 8 tahun tetapi belum mencapai usia 18 tahun dan belum pernah menikah. ${ }^{11}$ Bahkan Undang-Undang Nomor 11 Tahun 2012 tentang Sistem Peradilan Pidana Anak yang baru akan diberlakukan pada tanggal 30 Juli 2014 menggantikan UndangUndang tentang Pengadilan Anak menentukan anak yang berkonflik dengan hukum yang selanjutnya disebut anak adalah anak yang telah berumur 12 tahun, tetapi belum berumur 18 tahun yang diduga melakukan tindak pidana. ${ }^{12}$

Selain definisi yang ditetapkan perundangundangan masih terdapat definisi anak menurut hukum Islam dan hukum adat. Menurut hukum Islam dan hukum adat sama-sama menentukan seseorang masih anak-anak atau sudah dewasa bukan dari usia anak, hal ini karena masing-masing anak berbeda usia untuk mencapai tingkat kedewasaan. ${ }^{13}$

Salah satu penyebab terjadinya tindak pidana kecelakaan lalu lintas khususnya bagi anak adalah tidak dipenuhinya syarat-syarat berlalu lin-

8 Lihat Pasal 292, 294, 295 dan Pasal 297 KUHP, lihat juga Pasal 1 Ayat (2) Undang-Undang Nomor 4 Tahun 1979 tentang Kesejahteraan Anak, lihat juga Pasal 330 KUHPerdata, lihat juga Pasal 1 Angka 2 Peraturan Pemerintah Nomor 2 Tahun 1988 tentang Usaha Kesejahteraan Anak Bagi Anak Yang Mempunyai Masalah.

9 Lihat Pasal 47 Ayat (2) dan Pasal 50 Ayat (1)UndangUndang Nomor 1 Tahun 1974 tentang Perkawinan, lihat juga Konvensi PBB tentang Hak-Hak Anak yang diratifikasi oleh Pemerintah R.I. dengan Keputusan Presiden Nomor 36 Tahun 1990 tanggal 6 Januari 1990.

10 Lihat Pasal 1 Angka 1 Undang-Undang Nomor 23 Tahun 2002 tentang Perlindungan Anak.

11 Lihat Pasal 1 Angka 1 Undang-Undang Nomor 3 Tahun 1997 tentang Pengadilan Anak.

12 Lihat Pasal 1 Angka 3 Undang-Undang Nomor 11 Tahun 2012 tentang Sistem Peradilan Pidana Anak.

13 Marlina, 2012. Peradilan Pidana Anak Di Indonesia Pengembangan Konsep Diversi dan Restorative Justice, PT. Refike Aditama, Bandung, hal. 34. 
tas sesuai ketentuan hukum yang berlaku, diantaranya memiliki SIM (Surat Izin Mengemudi) dan keterampilan mengendarai kendaraan bermotor. Untuk mendapatkan Surat Izin Mengemudi (SIM), pengemudi harus terlebih dahulu memenuhi persyaratan yang terdiri dari, persyaratan usia, administratif, kesehatan, dan lulus ujian. Hal ini seringkali diabaikan oleh para orang tua yang memiliki anak dan sudah berani mengendarai kendaraan bermotor. Undang-Undang Lalu Lintas dan Angkutan Jalan telah mengatur syarat-syarat tersebut dalam Pasal 81 sebagai berikut:

(1) Untuk mendapatkan Surat Izin Mengemudi sebagaimana dimaksud dalam Pasal 77 , setiap orang harus memenuhi persyaratan usia, administratif, kesehatan, dan lulus ujian.

(2) Syarat usia sebagaimana dimaksud pada ayat (1) ditentukan paling rendah sebagai berikut:

a. usia 17 (tujuh belas) tahun untuk Surat Izin Mengemudi A, Surat Izin Mengemudi $C$, dan Surat Izin Mengemudi D;

b. usia 20 (dua puluh) tahun untuk Surat Izin Mengemudi B I; dan

c. usia 21 (dua puluh satu) tahun untuk Surat Izin Mengemudi B II.

(3) Syarat administratif sebagaimana dimaksud pada ayat (1) meliputi:

a. identitas diri berupa Kartu Tanda Penduduk;

b. pengisian formulir permohonan; dan

c. rumusan sidik jari.

(4) Syarat kesehatan sebagaimana dimaksud pada ayat (1) meliputi:

a. sehat jasmani dengan surat keterangan dari dokter; dan

b. sehat rohani dengan surat lulus tes psikologis.

(5) Syarat lulus ujian sebagaimana dimaksud pada ayat (1) meliputi:

a. ujian teori;

b. ujian praktik; dan/atau

c. ujian keterampilan melalui simulator.

(6) Selain persyaratan sebagaimana dimaksud pada ayat (2), ayat (3), ayat (4) dan ayat (5), setiap pengemudi kendaraan bermotor yang akan mengajukan permohonan :

a. Surat Izin Mengemudi $\mathrm{BI}$ harus memiliki Surat Izin Mengemudi A seku- rang-kurangnya 12 (dua belas) bulan ; dan

b. Surat Izin Mengemudi Bll harus memiliki Surat Izin Mengemudi BI sekurang-kurangnya 12 (dua belas) bulan.

Terdapat dua ukuran kealpaan dilihat dari sudut kecerdasan atau kekuatan ingatan pelaku, yaitu : (1) culpa lata, yaitu si pelaku telah berbuat kesalahan yang menyolok atau berat, dan (2) culpa levis, yaitu si pelaku telah berbuat kesalahan yang ringan. Dari kedua ukuran tersebut, pendapat para sarjana, jenis kealpaan yang digunakan oleh undang-undang adalah culpa lata atau schuld yang menyolok atau menonjol, yaitu sebagaimana tampak pada Pasal 359, Pasal 360 dan Pasal 480 KUHP. Arrest Hoge Raad tanggal 14 November 1887-W.5509, 3 Februari 1913W.9459, N.I. 1913, 571 dan 25 April 1916 dan sebagainya menentukan bahwa kealpaan harus memenuhi kekuranghati-hatian yang besar/berat, kesembronoan yang besar atau kealpaan yang besar. Jadi untuk suatu kejahatan yang dilakukan dengan kealpaan ringan (culpa levis) tidak dipertanggungjawab-pidanakan kepada pelaku.

Menentukan kekuranghati-hatian dari si pelaku dapat dipergunakan ukuran apakah ia "ada kewajiban untuk berbuat lain". Kewajiban ini dapat diambil dari ketentuan undang-undang atau dari luar undang-undang, yaitu dengan memperhatikan segala keadaan apakah yang seharusnya dilakukan olehnya. Kalau ia tidak melakukan apa yang seharusnya ia lakukan, maka hal tersebut menjadi dasar untuk dapat mengatakan bahwa ia alpa. Di dalam undang-undang mewajibkan seseorang untuk melakukan sesuatu atau tidak melakukan sesuatu, misalnya apabila pengendara berbuat lain dari apa yang diatur maka apabila terjadi tabrakan sehingga orang lain luka berat, maka ia dapat dikatakan karena kealpaannya mengakibatkan orang lain luka berat. Di luar undangundang pun ada aturan-aturan, yaitu berupa kebiasaan atau kepatutan dalam pergaulan hidup masyarakat yang harus diindahkan oleh seseorang. Misalnya, ada orang menghidupkan mesin mobilnya pada waktu mengisi bensin, apabila hal 
tersebut mengakibatkan kebakaran yang membahayakan keselamatan harta benda atau seseorang maka ia dapat dikatakan berbuat kealpaan dan dapat dipidana.

Di dalam praktek peradilan, dapat dipicananya perbuatan kealpaan atau kelalaian dapat terjadi dengan pelaku penyertaan (culpose deelneming). Hal ini dapat dilihat dari Arrest Hoge Raad 14 November 1921 terhadap perkara tindak pidana dalam Pasal 195 KUHP yaitu "Barang siapa karena kealpaannya terjadi suatu bahaya bagi lalu lintas umum yang digerakan oleh tenaga uap/mesin di jalan kereta api”, ternyata memutuskan bahwa dalam hal tersebut mungkin terjadi penyertaan. Dalam suatu kasus kecelakaan kereta api di mana terlibat sebagai terdakwa-terdakwanya antara lain kepala stasion dan seorang pengatur perjalanan kereta api dikatakan bahwa kecelakaan telah terjadi karena kerjasama dalam arti kealpaan yang besar dari kedua terdakwa tersebut. Dinyatakan bahwa bentuk pelaku penyertaan untuk melakukan delik Pasal 195 telah terjadi, karena tindakan masing-masing pelaku penyerta, satu sama lain berhubungan erat dalam rangka terwujudnya kecelakaan itu dikehendaki oleh undang-undang.

\section{Bentuk-Bentuk Ajaran Penyertaan yang Dapat Diterapkan dalam Tindak Pidana Kecelakaan Lalu Lintas yang Dilakukan oleh Anak di Wila- yah Hukum Pengadilan Negeri Purworejo.}

Mengenai ajaran penyertaan dalam hukum pidana di Indonesia, terdapat beberapa istilah yang digunakan, diantaranya Tresna menggunakan istilah "turut campur dalam peristiwa pidana". Penyertaan (deelneming) adalah pengertian yang meliputi semua bentuk turut serta/terlibatnya orang atau orang-orang baik secara psikis maupun fisik dengan melakukan masing-masing perbuatan sehingga melahirkan suatu tindak pidana. ${ }^{14}$ Orang-orang yang terlibat dalam kerja sama yang mewujudkan tindak pidana, perbuatan masing-masing dari mereka berbeda satu dengan

14 Adami Chazawi, Op. Cit., hal. 69. yang lain, demikian juga bisa tidak sama apa yang ada dalam sikap batin mereka terhadap tindak pidana maupun terhadap peserta yang lain. Tetapi dari perbedaan-perbedaan yang ada pada masing-masing itu terjalinlah suatu hubungan yang sedemikian rupa eratnya, dimana perbuatan yang satu menunjang perbuatan yang lainnya, yang semuanya mengarah pada satu ialah terwujudnya tindak pidana.

Ada dua pandangan tentang sifat penyertaan: ${ }^{15}$ (1) Sebagai strafausdeh-nungsgrund (dasar memperluas dapat dipidananya orang). Penyertaan dipandang sebagai persoalan pertanggunganjawaban pidana. Penyertaan bukan suatu delik sebab bentuknya tidak sempurna. Penganutnya antara lain: Simons, van Hattum, Hazewinkel-Suringa; (2) Sebagai tatbestandausdehnungsgrund (dasar memperluas dapat dipidananya perbuatan). Penyertaan dipandang bentuk khusus dari tindak pidana. Penyertaan merupakan suatu delik, hanya bentuknya istimewa. Penganutnya antara lain: Pompe, Moeljatno, dan Roeslan Saleh.

Adapun hasil pengamatan Penulis terhadap perkara khusus tindak pidana kecelakaan lalu lintas yang masuk ke Pengadilan Negeri Purworejo diperoleh data sebagai berikut $:^{16}$

Tabel 1: Jumlah Perkara Tindak Pidana Kecelakaan Lalu Lintas Masuk ke Pengadilan Negeri Purworejo

\begin{tabular}{|c|c|c|c|c|c|}
\hline No & Th & $\begin{array}{c}\text { Perkara } \\
\text { Masuk }\end{array}$ & Dewasa & Anak & Ket. \\
\hline 1 & 2012 & $\begin{array}{c}15 \\
\text { perkara }\end{array}$ & $\begin{array}{c}13 \\
\text { perkara }\end{array}$ & $\begin{array}{l}\text { Seluruhnya } \\
\text { perkara } \\
\text { dengan } \\
\text { dakwaan } \\
\text { melanggar } \\
\text { Pasal 310 } \\
\text { Undang- } \\
\text { Undang } \\
\text { Nomor 22 }\end{array}$ \\
\hline
\end{tabular}

15 Barda Nawawi Arief, Kebijakan Legislatif dalam Penanggulangan Kejahatan dengan Pidana Penjara, Badan Penerbit Undip, Semarang, hal. 28

16 Laporan Tahunan Pengadilan Negeri Purworejo 2012 dan 2013, dan hasil wawancara dengan Sri Rahayuningsih Hakim Pengawas Pidana Pengadilan Negeri Purworejo pada hari Senin tanggal 6 Januari 2014. 


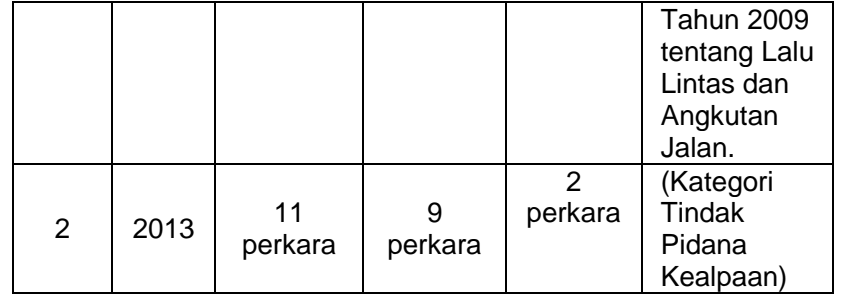

Tabel 2: Perkara Anak Tindak Pidana Kecelakaan Lalu Lintas Tahun 2012 di Pengadilan Negeri Purworejo

\begin{tabular}{|c|c|c|c|c|}
\hline No. & $\begin{array}{c}\text { No. } \\
\text { Perkara }\end{array}$ & Dakwaan & Putusan & Ket. \\
\hline 1 & $\begin{array}{l}\text { 30/Pid.Sus/ } \\
\text { AN/2012/P } \\
\text { N.Pwr. }\end{array}$ & $\begin{array}{l}\text { Pasal } 310 \\
\text { Ayat (4) } \\
\text { Undang- } \\
\text { Undang } \\
\text { Nomor } 22 \\
\text { Tahun } \\
2009 .\end{array}$ & $\begin{array}{l}\text { Pidana } \\
\text { Penjara } \\
\text { selama } 3 \\
\text { (tiga) } \\
\text { bulan dan } \\
15 \text { (lima } \\
\text { belas) } \\
\text { hari. }\end{array}$ & $\begin{array}{l}\text { Telah } \\
\text { berkeku } \\
\text { atan } \\
\text { hukum } \\
\text { tetap. }\end{array}$ \\
\hline 2 & $\begin{array}{l}\text { 54/Pid.Sus/ } \\
\text { AN/2012/P } \\
\text { N.Pwr. }\end{array}$ & $\begin{array}{l}\text { Pasal } 310 \\
\text { Ayat (4) } \\
\text { Undang- } \\
\text { Undang } \\
\text { Nomor } 22 \\
\text { Tahun } \\
2009 .\end{array}$ & $\begin{array}{l}\text { Pidana } \\
\text { Penjara } \\
\text { selama } 6 \\
\text { (enam) } \\
\text { bulan } \\
\text { dengan } \\
\text { masa } \\
\text { percobaan } \\
\text { selama } 1 \\
\text { (satu) } \\
\text { tahun. }\end{array}$ & $\begin{array}{l}\text { Telah } \\
\text { berkeku } \\
\text { atan } \\
\text { hukum } \\
\text { tetap. }\end{array}$ \\
\hline
\end{tabular}

Tabel 3: Perkara Anak Tindak Pidana Kecelakaan Lalu Lintas Tahun 2013 di Pengadilan Negeri Purworejo

\begin{tabular}{|c|c|c|c|c|}
\hline No & $\begin{array}{c}\text { No. } \\
\text { Perkara }\end{array}$ & Dakwaan & Putusan & Keterangan \\
\hline 1. & $\begin{array}{l}\text { 16/Pid.Sus } \\
\text { /AN/2013/ } \\
\text { PN.Pwr. }\end{array}$ & $\begin{array}{l}\text { Pasal } 310 \\
\text { Ayat (3) } \\
\text { Undang- } \\
\text { Undang } \\
\text { Nomor } 22 \\
\text { Tahun } \\
2009 .\end{array}$ & $\begin{array}{l}\text { Pidana } \\
\text { Penjara } \\
\text { selama } 8 \\
\text { (delapan) } \\
\text { bulan. }\end{array}$ & $\begin{array}{l}\text { Telah } \\
\text { berkekuatan } \\
\text { hukum } \\
\text { tetap. }\end{array}$ \\
\hline 2. & $\begin{array}{l}\text { 26/Pid.Sus } \\
\text { /AN/2013/ } \\
\text { PN.Pwr. }\end{array}$ & $\begin{array}{l}\text { Pasal } 310 \\
\text { Ayat (4) } \\
\text { Undang- } \\
\text { Undang } \\
\text { Nomor } 22\end{array}$ & $\begin{array}{l}\text { Pidana } \\
\text { Penjara } \\
\text { selama } 3 \\
\text { (tiga) bulan } \\
\text { dengan }\end{array}$ & $\begin{array}{l}\text { Telah } \\
\text { berkekuatan } \\
\text { hukum } \\
\text { tetap. }\end{array}$ \\
\hline
\end{tabular}

\begin{tabular}{|l|l|l|l|}
\hline & $\begin{array}{l}\text { Tahun } \\
2009 .\end{array}$ & $\begin{array}{l}\text { masa } \\
\text { percobaan } \\
\text { selama 6 } \\
\text { (enam) } \\
\text { tahun. }\end{array}$ & \\
& & & \\
\hline
\end{tabular}

Tabel 4: Fakta Hukum dan Keadaan Perkara Anak Tindak Pidana Kecelakaan Lalu Lintas di Pengadilan Negeri Purworejo Tahun 2012-2013

\begin{tabular}{|c|c|c|c|}
\hline No & $\begin{array}{c}\text { No. } \\
\text { Perkara }\end{array}$ & Dakwaan & $\begin{array}{l}\text { Fakta Hukum dan } \\
\text { Keadaan }\end{array}$ \\
\hline 1 & $\begin{array}{l}\text { 30/Pid.Sus } \\
\text { /AN/2012/ } \\
\text { PN.Pwr. }\end{array}$ & $\begin{array}{l}\text { Pasal } 310 \\
\text { Ayat (4) } \\
\text { Undang- } \\
\text { Undang } \\
\text { Nomor } 22 \\
\text { Tahun } \\
2009 .\end{array}$ & $\begin{array}{l}\text { - Terdakwa tidak } \\
\text { memiliki SIM C. } \\
\text { - Terdakwa } \\
\text { mengendarai sepeda } \\
\text { motor dengan } \\
\text { kecepatan tinggi } \\
\text { karena situasi hujan. } \\
\text { - Terdakwa tidak } \\
\text { membunyikan klakson } \\
\text { saat mendahului } \\
\text { kendaraan lain dan } \\
\text { mengendarai dengan } \\
\text { satu tangan di stang. } \\
\text { - Terdakwa pelajar } \\
\text { SMA }\end{array}$ \\
\hline 2 & $\begin{array}{l}\text { 54/Pid.Sus } \\
\text { /AN/2012/ } \\
\text { PN.Pwr. }\end{array}$ & $\begin{array}{l}\text { Pasal } 310 \\
\text { Ayat (4) } \\
\text { Undang- } \\
\text { Undang } \\
\text { Nomor } 22 \\
\text { Tahun } \\
2009 .\end{array}$ & $\begin{array}{l}\text { - Terdakwa tidak } \\
\text { memiliki SIM C. } \\
\text { - Terdakwa } \\
\text { mengendarai sepeda } \\
\text { motor dengan } \\
\text { kecepatan tinggi. } \\
\text { - Terdakwa tidak } \\
\text { membunyikan klakson } \\
\text { dan menyalakan } \\
\text { lampu motor. } \\
\text { - Terdakwa pelajar } \\
\text { SMP }\end{array}$ \\
\hline 3 & $\begin{array}{l}\text { 16/Pid.Sus } \\
\text { /AN/2013/ } \\
\text { PN.Pwr. }\end{array}$ & $\begin{array}{l}\text { Pasal } 310 \\
\text { Ayat (3) } \\
\text { Undang- } \\
\text { Undang } \\
\text { Nomor } 22 \\
\text { Tahun } \\
2009 .\end{array}$ & $\begin{array}{l}\text { - Terdakwa tidak } \\
\text { memiliki SIM C. } \\
\text { - Terdakwa } \\
\text { mengendarai sepeda } \\
\text { motor dengan } \\
\text { kecepatan tinggi. } \\
\text { - } \text { Terdakwa tidak } \\
\text { membunyikan } \\
\text { klakson, tidak } \\
\text { mengenakan helm } \\
\text { dan menyalakan } \\
\text { lampu motor. } \\
\text { - Terdakwa pelajar } \\
\text { SMK }\end{array}$ \\
\hline
\end{tabular}




\begin{tabular}{|c|c|c|c|}
\hline & & & $\begin{array}{l}\text { - Orang tua } \\
\text { membolehkan } \\
\text { terdakwa } \\
\text { mengendarai sepeda } \\
\text { motor. }\end{array}$ \\
\hline 4. & $\begin{array}{l}\text { 26/Pid.Sus } \\
\text { /AN/2013/ } \\
\text { PN.Pwr. }\end{array}$ & $\begin{array}{l}\text { Pasal } 310 \\
\text { Ayat (4) } \\
\text { Undang- } \\
\text { Undang } \\
\text { Nomor } 22 \\
\text { Tahun } \\
2009 .\end{array}$ & $\begin{array}{l}\text { - Terdakwa tidak } \\
\text { memiliki SIM C. } \\
\text { - Terdakwa tidak } \\
\text { membunyikan } \\
\text { klakson, tidak } \\
\text { mengenakan helm } \\
\text { dan menyalakan } \\
\text { lampu motor. } \\
\text { - Terdakwa pelajar } \\
\text { SMA. } \\
\text { - Orang tua mengetahui } \\
\text { terdakwa } \\
\text { mengendarai sepeda } \\
\text { motor. }\end{array}$ \\
\hline
\end{tabular}

Data di atas relevan dengan hasil pengamatan Penulis terhadap perkara anak tindak pidana kecelakaan lalu lintas yang masuk ke Pengadilan Negeri Purworejo melalui register perkara pidana khusus di Kepaniteraan Pidana, bahwa ternyata tidak ditemukan adanya perkara pidana yang melibatkan orang tua pelaku untuk dimintai pertanggungjawaban pidana atas turut andil atau ikut sertanya dalam tindak pidana kecelakaan lalu lintas yang dilakukan oleh anak (penyertaan orang tua), meski dalam pemeriksaan ditemukan fakta bahwa orang tua menyadari anaknya belum memiliki SIM (Surat Izin Mengemudi) namun tetap dibolehkan mengendarai kendaraan bermotor. Hal ini didukung dengan penjelasan dari Nur Sricahyawijaya, Kepala Seksi Tindak Pidana Umum (Kasipidum)/Jaksa Penuntut Umum pada Kejaksaan Negeri Purworejo yang menyebutkan bahwa selama ini belum ada petunjuk pelaksanaan dari pimpinan kejaksaan Menegnai perkara anak tindak pidana kecelakaan lalu lintas yang dapat pula menyeret orang tuanya untuk dimintai pertanggungjawaban pidana. ${ }^{17}$

17 Hasil Wawancara Penulis dengan Nur Sricahyawijaya, Kepala Seksi Tindak Pidana Umum (Kasipidum)/Jaksa Penuntut Umum pada Kejaksaan Negeri Purworejo, pada hari Rabu tanggal 8 Januari 2014.

\section{Ajaran Penyertaan dalam Tindak Pidana Kece-} lakaan Lalu Lintas yang Dilakukan oleh Anak

Anak adalah bagian yang tidak terpisahkan dari keberlangsungan hidup manusia dan keberlangsungan sebuah bangsa dan negara. Dalam konstitusi negara kita dinyatakan anak memiliki peran strategis yang secara tegas dinyatakan bahwa negara menjamin hak setiap anak atas kelangsungan hidup, tumbuh dan berkembang serta atas perlindungan dari kekerasan dan diskriminasi. Oleh karenanya kepentingan terbaik bagi anak patut dihayati sebagai kepentingan terbaik bagi kelangsungan hidup umat manusia.

Undang-Undang Nomor 39 Tahun 1999 tentang Hak Asasi Manusia telah mencantumkan tentang hak anak, dan pelaksanaan kewajiban dan tanggung jawab orang tua, keluarga, masyarakat, pemerintah, dan negara untuk memberikan perlindungan pada anak telah dijamin dalam ketentuan perundang-undangan Republik Indonesia, diantaranya Undang-Undang Nomor 4 Tahun 1979 tentang Kesejahteraan Anak, Undang-Undang Nomor 3 Tahun 1997 tentang Pengadilan Anak, Undang-Undang Nomor 23 Tahun 2002 tentang Perlindungan Anak dan terakhir dengan Undang-Undang Nomor 11 Tahun 2012 tentang Sistem Peradilan Pidana Anak yang akan diberlakukan menggantikan Undang-Undang Nomor 3 Tahun 1997 tentang Pengadilan Anak nanti pada tanggal 30 Juli 2014. Secara substansinya undang-undang tersebut mengatur hak-hak anak yang berupa, hak hidup, hak atas nama, hak pendidikan, hak kesehatan dasar, hak untuk beribadah menurut agamanya, hak berekspresi, berpikir, bermain, berkreasi, beristirahat, bergaul dan hak jaminan sosial. Dibuatnya aturan-aturan tersebut terlihat bahwa negara sangat memperhatikan dan melindungi hak-hak anak yang wajib dijunjung tinggi oleh setiap orang. Pengadilan anak dibentuk sebagai upaya pembinaan dan perlindungan dalam rangka menjamin pertumbuhan dan perkembangan fisik, mental dan sosial anak secara utuh, serasi, selaras dan seimbang. Hal ini penting, karena perlindungan anak dalam segala aspeknya merupakan bagian dari kegiatan pem- 
bangunan nasional, khususnya dalam memajukan kehidupan berbangsa dan bernegara.

Diantara kriminalitas dengan pelaku anak yang menarik perhatian publik adalah kenakalan anak yang menjurus pada tindak pidana kecelakaan lalu lintas. Hal ini tidak hanya dipicu oleh kejadian kecelakaan lalu lintas yang menimpa AQJ anak musisi Ahmad Dani yang disebut-sebut sebagai "sopir maut" yang masih berusia 13 (tigabelas) tahun namun diperbolehkan mengenadarai mobil yang mengakibatkan kecelakaan lalu lintas pada tanggal 8 September 2013 di Tol Jagorawi dengan korban 7 (tujuh) orang meninggal dunia dan lainnya luka-luka, tetapi disebabkan kasus serupa banyak terjadi di daerahdaerah termasuk di Kabupaten Purworejo. Hal ini telah menyita perhatian masyarakat, Lembaga Swadaya Masyarakat (LSM) pemerhati anak, praktisi hukum maupun para akademisi.

Penjelasan Undang-Undang Nomor $22 \mathrm{Ta}$ hun 2009 tentang Lalu Lintas dan Angkutan Jalan, terdapat alasan mendasar mengenai harus dipenuhinya syarat usia untuk mendapatkan Surat Izin Mengemudi (SIM), yaitu untuk menjamin terwujudnya penyelenggaraan lalu lintas dan angkutan jalan yang memenuhi standar keselamatan dan keamanan. Sedangkan untuk menangani masalah kecelakaan lalu lintas, pencegahan kecelakaan dilakukan melalui partisipasi para pemangku kepentingan, pemberdayaan masyarakat, penegakan hukum dan kemitraan global. Tersedianya sanksi pidana bagi pelanggar, dimaksudkan agar dapat menimbulkan efek jera bagi pelaku pelanggaran dengan tidak terlalu membebani masyarakat.

Kecelakaan lalu lintas adalah suatu peristiwa di jalan yang tidak diduga dan tidak disengaja melibatkan kendaraan dengan atau tanpa pengguna jalan lain yang mengakibatkan korban manusia dan/atau kerugian harta benda. ${ }^{18}$ Dikualifikasinya tindak pidana kecelakaan lalu lintas sebagai kejahatan oleh Undang-Undang Nomor 22 Tahun 2009 tentang Lalu Lintas dan Angkutan

18 Lihat Pasal 1angka 24 Undang-Undang Nomor 22 Tahun 2009 tentang Lalu Lintas dan Angkutan Jalan.
Jalan, tindak pidana kecelakaan lalu lintas dalam bentuk kealpaan atau kelalaian diatur dalam ketentuan Pasal 310 Undang-Undang Nomor 22 Tahun 2009 tentang Lalu Lintas dan Angkutan Jalan.

Salah satu penyebab terjadinya tindak pidana kecelakaan lalu lintas khususnya bagi anak adalah tidak dipenuhinya syarat-syarat berlalu lintas sesuai ketentuan hukum yang berlaku, diantaranya memiliki SIM (Surat Izin Mengemudi) dan keterampilan mengendarai kendaraan bermotor. Untuk mendapatkan Surat Izin Mengemudi (SIM), pengemudi harus terlebih dahulu memenuhi persyaratan yang terdiri dari, persyaratan usia, administratif, kesehatan, dan lulus ujian. Hal ini seringkali diabaikan oleh para orang tua yang memiliki anak dan sudah berani mengendarai kendaraan bermotor. Undang-Undang Lalu Lintas dan Angkutan Jalan telah mengatur syarat-syarat tersebut dalam Pasal 81 sebagaimana telah disebutkan diatas.

Ketentuan hukum di atas, dalam Penjelasan Undang-Undang Nomor 22 Tahun 2009 tentang Lalu Lintas dan Angkutan Jalan, terdapat alasan mendasar mengenai harus dipenuhinya syarat usia untuk mendapatkan Surat Izin Mengemudi (SIM), yaitu untuk menjamin terwujudnya penyelenggaraan lalu lintas dan angkutan jalan yang memenuhi standar keselamatan dan keamanan. Sedangkan untuk menangani masalah kecelakaan lalu lintas, pencegahan kecelakaan dilakukan melalui partisipasi para pemangku kepentingan, pemberdayaan masyarakat, penegakan hukum dan kemitraan global. Tersedianya sanksi pidana bagi pelanggar, dimaksudkan agar dapat menimbulkan efek jera bagi pelaku pelanggaran dengan tidak terlalu membebani masyarakat.

Tindak pidana kecelakaan lalu lintas dalam bentuknya sebagai delik kelalaian atau disebut juga kealpaan (culpose delicten) yaitu tindak pidana yang unsur kesalahannya berupa kelalaian, kurang hati-hati, dan tidak karena kesengajaan. KUHP tidak memberikan definisi kealpaan atau culpa. Namun menurut M.v.T (memorie van 
toelichting): kealpaan di satu fihak berlawanan benar-benar dengan kesengajaan dan di fihak lain dengan hal yang kebetulan (toefel atau casus).

Terdapat dua ukuran kealpaan dilihat dari sudut kecerdasan atau kekuatan ingatan pelaku, yaitu : (1) culpa lata, yaitu si pelaku telah berbuat kesalahan yang menyolok atau berat, dan (2) culpa levis, yaitu si pelaku telah berbuat kesalahan yang ringan. Dari kedua ukuran tersebut, pendapat para sarjana, jenis kealpaan yang digunakan oleh undang-undang adalah culpa lata atau schuld yang menyolok atau menonjol, yaitu sebagaimana tampak pada Pasal 359, Pasal 360 dan Pasal 480 KUHP. Arrest Hoge Raad tanggal 14 November 1887-W.5509, 3 Februari 1913W.9459, N.I. 1913, 571 dan 25 April 1916 dan sebagainya menentukan bahwa kealpaan harus memenuhi kekuranghati-hatian yang besar/berat, kesembronoan yang besar atau kealpaan yang besar. Jadi untuk suatu kejahatan yang dilakukan dengan kealpaan ringan (culpa levis) tidak dipertanggungjawab-pidanakan kepada pelaku.

Dilihat dari sudut kesadaran (bewustheid), terdapat dua tingkatan kealpaan, yaitu: (1) kealpaan yang disadari (bewuste schuld), yaitu jika pelaku dapat membayangkan/memperkirakan akan timbulnya suatu akibat. Tetapi ketika ia melakukan tindakannya dengan usaha pencegahan supaya tidak timbul akibat itu, namun akibat itu timbul juga; dan kealpaan yang tidak disadari (onbewuste schuld), yaitu bilamana pelaku tidak dapat memperkirakan akan timbulnya suatu akibat, tetapi seharusnya (menurut perhitungan umum/yang layak) pelaku dapat membayangkannya. Kealpaan yang tidak disadari biasanya terjadi karena ketololan, ketidaktahuan, terkejut, kecapaian atau keadaan pikiran dan/atau jiwa seseorang sehingga tak dapat memperkirakan akibat dari tindakannya itu. Terhadap kealpaan yang tidak disadari maka pelaku tidak dituntut pertanggungjawaban pidana, atau dengan perkataan lain tidak ada pemidanaan, hal ini disebabkan di samping karena alasan sulitnya dalam pembuktian juga tidak ada faedahnya memidana seseorang yang hubungan jiwa dan tindakannya terhadap akibat yang terjadi, hampir-hampir tidak ada. Pendirian ini ditemukan dalam Arrest Hoge Raad tanggal 21 November 1932, N.J. 1933, 153: 6 Juni 1933, N.J. 193, 1299; 24 Mei 1937, W. dan N.J. 1937 No. 1162 dan sebagainya.

Di dalam praktek peradilan, dapat dipidananya perbuatan kealpaan atau kelalaian dapat terjadi dengan pelaku penyertaan (culpose deelneming). Hal ini dapat dilihat dari Arrest Hoge Raad 14 November 1921 terhadap perkara tindak pidana dalam Pasal 195 KUHP yaitu "Barang siapa karena kealpaannya terjadi suatu bahaya bagi lalu lintas umum yang digerakkan oleh tenaga uap/mesin di jalan kereta api", ternyata memutuskan bahwa dalam hal tersebut mungkin terjadi penyertaan. Dalam suatu kasus kecelakaan kereta api di mana terlibat sebagai terdakwa-terdakwanya antara lain kepala stasion dan seorang pengatur perjalanan kereta api dikatakan bahwa kecelakaan telah terjadi karena kerjasama dalam arti kealpaan yang besar dari kedua terdakwa tersebut. Dinyatakan bahwa bentuk pelaku penyertaan untuk melakukan delik $\mathrm{Pa}$ sal 195 telah terjadi, karena tindakan masingmasing pelaku penyerta, satu sama lain berhubungan erat dalam rangka terwujudnya kecelakaan itu dikehendaki oleh undang-undang.

Mengenai tindak pidana penyertaan atau yang disebut dengan istilah lain "turut campur dalam peristiwa pidana" atau "turut berbuat delik" atau "turut serta" atau "deelneming" telah diatur dalam Bab V KUHP tentang Penyertaan dalam melakukan perbuatan pidana yaitu Pasal 55 dan Pasal 56. Penyertaan (deelneming) adalah pengertian yang meliputi semua bentuk turut serta/terlibatnya orang atau orang-orang baik secara psikis maupun fisik dengan melakukan masingmasing perbuatan sehingga melahirkan suatu tindak pidana. Orang-orang yang terlibat dalam kerja sama yang mewujudkan tindak pidana, perbuatan masing-masing dari mereka berbeda satu dengan yang lain, demikian juga bisa tidak sama apa yang ada dalam sikap batin mereka terhadap tindak pidana maupun terhadap peserta yang lain. Tetapi dari perbedaan-perbedaan yang ada pada 
masing-masing itu terjalinlah suatu hubungan yang sedemikian rupa eratnya, dimana perbuatan yang satu menunjang perbuatan yang lainnya, yang semuanya mengarah pada satu ialah terwujudnya tindak pidana.

\section{Bentuk-Bentuk Ajaran Penyertaan yang Dapat Diterapkan dalam Tindak Pidana Kecelakaan Lalu Lintas yang Dilakukan oleh Anak di Wila- yah Hukum Pengadilan Negeri Purworejo.}

Data di atas relevan dengan hasil pengamatan Penulis terhadap perkara anak tindak pidana kecelakaan lalu lintas yang masuk ke Pengadilan Negeri Purworejo melalui register perkara pidana khusus di Kepaniteraan Pidana, bahwa ternyata tidak ditemukan adanya perkara pidana yang melibatkan orang tua pelaku untuk dimintai pertanggungjawaban pidana atas turut andil atau ikut sertanya dalam tindak pidana kecelakaan lalu lintas yang dilakukan oleh anak (penyertaan orang tua), meski dalam pemeriksaan ditemukan fakta bahwa orang tua menyadari anaknya belum memiliki SIM (Surat Izin Mengemudi) namun tetap dibolehkan mengendarai kendaraan bermotor. Hal ini didukung dengan penjelasan dari Nur Sricahyawijaya, Kepala Seksi Tindak Pidana Umum (Kasipidum)/Jaksa Penuntut Umum pada Kejaksaan Negeri Purworejo yang menyebutkan bahwa selama ini belum ada petunjuk pelaksanaan dari pimpinan kejaksaan mengenai perkara anak tindak pidana kecelakaan lalu lintas yang dapat pula menyeret orang tuanya untuk dimintai pertanggungjawaban pidana. ${ }^{19}$

Mencermati putusan pengadilan atas 4 (empat) perkara anak tindak pidana kecelakaan dalam kurun waktu tahun 2012 sampai dengan 2013 ditemukan kesamaan fakta hukum dan keadaan yang dijadikan pertimbangan oleh Hakim dalam mengambil putusan diantaranya sebagai berikut:20 (1) bahwa terdakwa belum memiliki SIM

19 Hasil Wawancara Penulis dengan Nur Sricahyawijaya, Kepala Seksi Tindak Pidana Umum (Kasipidum)/Jaksa Penuntut Umum pada Kejaksaan Negeri Purworejo, pada hari Rabu tanggal 8 Januari 2014.

20 Diambil dari Putusan Nomor 16/Pid.Sus/AN/2013/PN.Pwr tanggal 14 Mei 2013, hal. 12-13, dan Putusan Nomor
C, dan sebelum terlibat kecelakaan lalu lintas mengendarai sepeda motor dengan kecepatan tinggi; (2) bahwa orang tua dan/atau keluarga terdakwa mengetahui terdakwa mengendarai sepeda motor yang tersedia di rumah dan membolehkan meski belum mempunyai SIM; (3) bahwa terdakwa saat mengendarai kendaraan tidak mengenakan helm dan tidak menyalakan lampu utama depan (light on); (4) bahwa terdakwa tidak membunyikan klakson terlebih dahulu saat hendak mendahului kendaraan lain di depannya, namun hanya menambah kecepatan; (5) bahwa terdakwa tidak menjaga jarak "aman" dengan pengendara di depannya.

Kenyataan di atas, memberikan gambaran betapa banyak ketidakmampuan secara teknis maupun pemikiran anak yang belum memiliki Surat Izin Mengemudi (SIM) dalam mengendarai kendaraan bermotor di jalan umum. Kondisi demikian menyulitkan pelaku anak untuk mengendalikan dan mencegah terjadinya kecelakaan lalu lintas. Adanya kerugian yang dapat dialami baik berupa kerugian materiil seperti biaya-biaya pengobatan, perbaikan kendaraan maupun kerugian moril yang berupa trauma, perasaan takut, khawatir dan lain sebagainya, di samping pidana itu sendiri yang harus dijalankan, mengancam pelaku anak. Fakta ini didukung dengan kenyataan di masyarakat yang dapat dilihat sehari-hari yaitu banyaknya anak-anak usia sekolah yang belum memenuhi syarat untuk mendapatkan Surat Izin Mengemudi (SIM), seperti siswa SMP dan SMA, namun oleh orang tuanya dibiarkan atau bahkan disediakan kendaraan bermotor untuk dikendarai ke tempat sekolahnya. Seolah-olah orang tua tidak menyadari bahwa bahaya kecelakaan lalu lintas dapat menimpa anak-anak tersebut. Hal ini terjadi karena orang tua tidak mampu dan tidak mau berbuat sesuatu untuk menjaga dan mencegah anaknya dari bahaya tindak pidana kecelakaan lalu lintas. Orang tua seringkali tidak menyadari bahwa perbuatannya ter-

26/Pid.Sus/AN/2013/PN.Pwr tanggal 30 Juli 2013, hal. 1819. 
sebut dapat memberikan andil dalam terjadinya tindak pidana yang melibatkan anaknya.

Di dalam Bab V KUHP mengatur mengenai semua bentuk turut serta/terlibatnya orang atau orang-orang baik secara psikis maupun fisik dengan melakukan masing-masing perbuatan sehingga melahirkan suatu tindak pidana, yang selanjutnya disebut dengan penyertaan dalam tindak pidana. Penyertaan atau dikenal dengan istilah lain deelneming atau "turut campur dalam peristiwa pidana" atau "turut berbuat delik" atau "turut serta".

Barda Nawawi Arief menjelaskan bahwa "menyuruh-lakukan (doenpleger)" dimungkinkan terjadi terhadap delik culpa (kelapaan), yaitu dalam hal orang yang menyuruh dapat menduga sebelumnya bahwa akan ada sesuatu akibat yang tidak diharapkan. Misal: A menyuruh seorang pekerja $B$ untuk melemparkan benda yang berat dari atap rumah ke bawah, tanpa menghiraukan apakah benda itu akan menimpa orang yang Kobetulan ada/lewat di bawah atap rumah itu. B mengira $A$ telah mengadakan pengamanan seperlunya. Jika karena lemparan itu ada orang tertimpa dan mati, maka A dapat dituntut karena menyuruh melakukan tindak pidana dalam Pasal 359 KUHP. Mengenai contoh ini, Pompe berpendapat A dapat dianggap sebagai pembuat. ${ }^{21}$

Barda Nawawi Arief lebih lanjut menjelaskan bahwa pada "turut serta", kesengajaannya ditujukan kepada: (1) kerjasama dengan orang lain (ditujukan pada perbuatan), dan; (2) tercapainya hasil yang merupakan delik (ditujukan pada akibat).

Di dalam delik culpa orang tidak menghendaki terjadinya akibat. Kalau kesengajaan orang yang turut serta juga harus ditujukan untuk timbulnya delik culpa tersebut, maka jelas tidak mungkin ada "turut serta melakukan" secara culpa. Akan tetapi jika kesengajaan itu hanya cukup ditujukan kepada adanya kerjasama, ialah kepada perbuatan yang dilakukan bersama, maka mungkin ada "turut serta melakukan" secara culpa.

${ }^{21}$ Barda Nawawi Arief, Op, Cit, hal. 33.
Misalnya, C memberi pelajaran kepada D mengendarai mobil di lapangan yang luas. $D$ duduk di belakang stuur dan $\mathrm{C}$ duduk di sampingnya memberi petunjuk-petunjuk. Pada waktu belajar itu, karena gugup D menabrak seseorang. Dalam hal itu ada turut serta melakukan perbuatan yang karena kealpaannya menyebabkan matinya orang lain (Pasal 55 jo. 359 KUHP). ${ }^{22}$

\section{Penutup \\ Simpulan}

Ajaran penyertaan dapat diterapkan dalam tindak pidana kecelakaan lalu lintas yang dilakukan oleh anak, yang usianya sekurang-kurangnya 12 (dua belas) tahun tetapi belum mencapai usia 18 (delapan belas) tahun dan belum pernah kawin. Hal ini didasarkan bahwa kedudukan orang tua sebagai penanggung jawab atas terwujudnya kesejahteraan anak baik secara rohani, jasmani maupun sosial, sudah sepantasnya menjadi pihak yang dapat turut dimintai pertanggungjawaban pidana di samping anak sebagai pelaku, dengan dasar memperluas pertanggungjawaban pidana (strafausdehnungs-grund).

Bentuk-bentuk penyertaan yang dapat diterapkan atas tindak pidana kecelakaan lalu lintas yang dilakukan oleh anak di wilayah hukum Pengadilan Negeri Purworejo sebagai berikut: (1) Penganjuran (uitlokking) dan pembantuan (medeplichtige) dalam jenisnya yang kedua yaitu Pembantu sebelum kejahatan dilakukan, jika orang tua memberikan kesempatan, menyediakan atau mengadakan kendaraan bermotor kepada anaknya yang belum memiliki SIM (Surat Izin Mengemudi) untuk dikendarai; (2) Menyuruh-lakukan (doenplegen), jika ternyata anak yang dianjurkan itu masih sangat muda sekali (belum mencapai usia 12 (dua belas) tahun), yang belum begitu sadar akan perbuatannya, maka dalam hal ini orang tua dimungkinkan ada menyuruh-lakukan; (3) Dalam praktek di wilayah hukum Pengadilan Negeri Purworejo bentuk-bentuk penyertaan dalam tindak

22 Ibid, hal. 35. 
pidana kecelakaan lalu lintas yang dilakukan oleh anak tidak diterapkan.

\section{Saran}

Peningkatan kualitas penegak hukum di bidang hukum materiil perlu diikuti dengan perkembangan hukum di masyarakat. Penegak hukum yang kompeten dalam hal ini penyidik anak, penuntut umum anak maupun hakim anak perlu dibekali pelatihan dan pendidikan khusus (sertifikasi) menangani perkara anak agar timbul kesadaran untuk berbuat demi kepentingan terbaik bagi anak. Pemahaman hukum atas fenomena banyaknya anak yang menjadi pelaku dalam tindak pidana kecelakaan lalu lintas perlu dicarikan solusi agar masa depan anak terjamin oleh hukum dengan baik, diantaranya dengan mempelajari teori dan doktrin-doktrin oleh para ahli hukum Menegnai penyertaan dalam tindak pidana, yang dapat diterapkan dalam kondisi masyarakat sekarang.

Penegak hukum harus berani berpikir maju dan progresif. Dapat dimintainya pertanggungjawaban pidana orang tua atas perbuatan yang dilakukan oleh anak dapat menghindarkan anak dalam proses peradilan pidana anak dan menimbulkan efek jera di kemudian hari. Masuknya konsep-konsep hukum dari Anglo-Saxon yang sudah diambilalih secara sadar atau tidak sadar, seperti dissenting opinion, dan whistleblower telah dijalankan dalam sistem hukum di negara Indonesia. Maka dengan interpretasi futuristik, orang tua anak yang menabrak orang lain dalam suatu kecelakaan lalu lintas sehingga jatuh korban baik mati atau luka-luka, dapat dipidana dan dituntut ganti kerugian, dengan menerapkan prinsip vicarious liability yang merupakan bentuk pertanggungjawaban pidana tanpa kesalahan.

\section{Daftar Pustaka Buku}

Amiruddin dan H. Zainal Asikin, 2004. Pengantar Metode Penelitian Hukum, PT. RajaGrafindo Persada, Jakarta.
Arief, Barda Nawawi, Kebijakan Legislatif dalam Penanggulangan Kejahatan dengan Pidana Penjara, Badan Penerbit Undip, Semarang.

Chazawi, Adami, 2010, Stelsel Pidana, Tindak Pidana, Teori-Teori Pemidanaan \& Batas Berlakunya Hukum Pidana, Pelajaran Hukum Pidana Bagian I, PT. Raja Grafindo Persada, Cetakan ke-5, Jakarta.

Gultom, Maidin, 2010. Perlindungan Hukum Terhadap Anak Dalam Sistem Peradilan Pidana Anak Di Indonesia, PT. Refika Aditama, Bandung.

Marlina, 2012. Peradilan Pidana Anak Di Indonesia Pengembangan Konsep Diversi dan Restorative Justice, PT. Refike Aditama, Bandung.

Sudarto, 1990. Hukum Pidana I, Yayasan Sudarto Fakultas Hukum Undip, Semarang.

Sianturi, S.R., Asas-Asas Hukum Pidana Di Indonesia Dan Penerapannya, Penerbit Alumni Ahaem-Petehaem, Jakarta

Soekanto, Soerjono, 1986. Pengantar Penelitian Hukum, UI Press, Jakarta.

-----------, 2001. Penelitian Hukum Normatif Suatu Tinjauan Singkat, Raja Grafindo, Jakarta.

Soemitro, Ronny Hanitijo, 1990. Metodologi Penelitian Hukum dan Yurimetri, Ghalia Indonesia, Jakarta.

Waluyo, Bambang, 2008. Pidana dan Pemidanaan, Sinar Grafika, Jakarta.

\section{Peraturan perundang-undangan}

Undang-Undang Nomor 1 Tahun 1974 tentang Perkawinan.

Undang-Undang Nomor 4 Tahun 1979 tentang Kesejahteraan Anak.

Undang-Undang Nomor 3 Tahun 1997 tentang Pengadilan Anak.

Undang-Undang Nomor 23 Tahun 2002 tentang Perlindungan Anak.

Undang-Undang Nomor 4 Tahun 2004 tentang Kekuasaan Kehakiman.

Undang-Undang Nomor 22 tahun 2009 tentang Lalu Lintas dan Angkutan Jalan.

Undang-Undang Nomor 11 Tahun 2012 tentang Sistem Peradilan Pidana Anak. 